\title{
Assessing preservation priorities of caves and karst areas using the frequency of endemic cave-dwelling species
}

\author{
Eugen Nitzu ${ }^{1 *}$, Marius Vlaicu ${ }^{1}$, Andrei Giurginca ${ }^{1}$, Ioana N. Meleg ${ }^{1}$, Ionut Popa ${ }^{1}$, \\ Augustin $\mathrm{Nae}^{1}$, and Ştefan Baba ${ }^{1,2}$ \\ 1"Emil Racoviță" Institute of Speleology, Romanian Academy, Calea 13 Septembrie, 050711, Bucharest, Romania \\ ${ }^{2}$ Faculty of Biology, University of Bucharest, Splaiul Independenței 91-95, 050095, Bucharest 5, Romania
}

\begin{abstract}
Endemic and rare species as bioindicators of habitat vulnerability were used to develop protection and management plans for biotope prioritization (mainly islands habitats, lava tubes or groundwaters). Due to their narrow distribution, the endemic species (species confined to a restricted geographic area) are more susceptible to ecological disequilibrium and habitat loss than the widespread ones. Consequently, endemics become endangered in the context of ecological disturbance caused by anthropogenic pressure, making them suitable candidates to assess environmental preservation needs. Taking into consideration that most of the stygobitic and troglobitic species are endemic and confined to specific karst areas, based on their association and frequency we propose an endemicity index $(E l)$ adapted to the fragmented nature of the cave habitat. We used a double ranking methodology: (1) ranking the endemic species according to their frequencies in caves, and (2) ranking the caves according to their El computed for a geographic area. Further, by mapping the caves based on their related $E I$, we identified the hotspots of vulnerable karst areas. The El has been developed using as case study of 380 caves from Romania, known up to now to be inhabited by a total of 278 endemic stygobitic and troglobitic species and subspecies. In our study area, 35 out of 380 caves with endemic species, narrowly distributed to karst areas of the Carpathian massifs and Dobrogea, had a considerable high El. The El proves to be highly sensitive to unique taxa (endemics recorded in only one cave) and also to other endemic taxa - recorded in more than one cave. However, all the endemites are confined to a specific geographic area (in this case of study - the Carpathians and Dobrogea karst area). El provides a reliable criterion to rank caves using the contribution of endemic species in order to assess cave and karst vulnerability and prioritize them for environment protection management.
\end{abstract}

Keywords: Arthropoda, Endemicity Index, karst areas vulnerability, stygobitic and troglobitic species, conservation priorities

Received 10 August 2017; Revised 22 November 2017; Accepted 22 November 2017

Citation: Nitzu E., Vlaicu M., Giurginca A., Meleg I.N., Popa I., Nae A. and Baba Ş., 2018. Assessing preservation priorities of caves and karst areas using the frequency of endemic cave-dwelling species. International Journal of Speleology, 47 (1), 43-52. Tampa, FL (USA) ISSN 0392-6672 https://doi.org/10.5038/1827-806X.47.1.2147

\section{INTRODUCTION}

Caves are inhabited by faunal communities that reveal significant heterogeneity in species composition, with aquatic (stygobitic) and terrestrial (troglobitic) specialist species, adapted to live underground, and also with generalist species, occurring accidentally or willingly underground. The fragmented nature of cave habitats and restricted opportunities for fauna dispersal (Sket, 1999) has led to a high number of narrowly-distributed subterranean taxa. These taxa contribute significantly to the local and regional species diversity and increase the conservation value of caves and karst areas (Stoch \& Galassi, 2010; Meleg et al., 2011). Consequently, the endemic stygobitic and troglobitic species should play an important role in assessing cave preservation priorities and karst area vulnerability. Prioritizing these endemic species for conservation purposes in karst areas is important: 1) due to their narrow distribution they are more susceptible to ecological disequilibrium and habitat loss (Cardoso et al., 2010), thus becoming endangered in the context of ecological disturbance caused by anthropogenic pressure in karst areas; 2) because they are good candidate species of conservation concern, the extinction of single-site endemics leading to loss of functional diversity with possible unpredictable consequences for ecosystem function at local scale 
(Harvey et al., 2017); 3) because they constitute a high proportion of the total richness of stygobitic (Michel et al., 2009) and troglobitic fauna (Juberthie, 2000).

Endemicity has been proven to be a useful tool in assessing environmental preservation priorities for surface natural habitats (Fattorini, 2010). Specifically, the use of (i) species rarity, (ii) vulnerability and (iii) extinction risk offer a reliable method in ranking priorities for preservation plans (Fattorini et al., 2013; Fattorini \& Dapporto, 2014). Considering these three concepts, Fattorini et al. (2013) stressed that 'endemics are typically considered as taxa of conservation concern', a topic addressed also by other authors (Myers \& De Grave, 2000; Cook \& MacDonald, 2001).

The endemic stygobitic and troglobitic species, not only are extremely rare, many of them with ranges strictly confined to a particular biotope (in some or few caves), but the majority of them are relic species which increases their value in terms of 'biological conservation concern'. For our study area (the Romanian Carpathians and Dobrogea) the fauna is mostly represented by species with Pliocene - Pleistocene origin (Decu \& Racoviță, 1994). Comprehensive information about evolutionary time for the troglobionts has been presented by Pipan \& Culver (2012). It is wor th mentioning that since 1947, biogeographers agreed to use two different terms, which are used in English just as in French, to define two biogeographic concepts: a relic is a species surviving from an ancient lineage; it has a very restricted distribution area. A relict is a species isolated from its normal distribution area (Udvardy, 1969).

Under these considerations, all caves with endemic stygobitic and troglobitic species should be included in protected areas, but as Meyers et al. (2000) pointed out, the integral protection desiderate is far to be achieved by conservationists due to the lack of funding. As the quoted authors mentioned this places a premium on priorities: how can we support the most species at the least cost?' One of the most effective and cost-efficient method to preserve natural habitats is considered to include them into protected areas (Ervin, 2003; Chape et al., 2005; Michel et al, 2009; Fattorini et al., 2012). For this, it is mandatory to establish criteria for identifying and prioritizing natural habitats by focusing their protection management on their vulnerabilities and requirements.

To our knowledge, for subterranean environments, species richness, distribution patterns and endemicity have been used successfully to propose schemes for: 1) groundwater fauna conservation during a large-scale project named PASCALIS (Protocol for the Assessment and Conservation of Aquatic Life In the Subsurface) conducted in six European regions (Gibert et al., 2009; Michel et al., 2009); 2) groundwater and karst conservation based on groundwater fauna distribution modeling in France and Romania (Castelarini et al., 2007; Meleg et al., 2014); 3) establishing cave conservation priorities based on terrestrial fauna in caves of Brazil (Jaffé et al., 2016); 4) ranking the lava tubes and volcanic pits for conservation purpose, based on multiple criteria index which also included endemic troglobitic species in Azorean Islands (Borges et al., 2004, 2012). However, none of these approaches were based on both aquatic and terrestrial subterranean fauna. Here we test how both aquatic and terrestrial subterranean species contribute to the use of endemicity to rank priority areas for cave and karst conservation in Romania, by proposing a Endemicity Index $(E I)$.

We have developed the EI starting from the concept and index of Biological Conservation Concern (BCC) proposed by Fattorini (2006) that aimed to classify terrestrial species (including the endemic species) into categories of endangerment and to weight them by their extinction risk.

As Fattorini \& Dapporto (2014) stressed, the BCC index is a 'relative measure' that is not sensitive to species richness and which poses some problems. On one hand, an assemblage with a single species having maximum weight of vulnerability would receive the same score of $B B C$ index as an assemblage with 10 species, all with maximum score, and, on the other hand, an assemblage with a single species with maximum weight has a higher score than an assemblage with 10 species, nine with maximum weight and one ranked with less weight than maximum. Due to this bias, in this paper, we propose an $E I$ adapted to the cave habitat to avoid the above mentioned shortcomings of the $B C C$ index.

Our aim was to assess the relevance and efficiency of applying endemicity and species richness as proxy for conservation prioritization of caves and karst areas by: 1) developing an endemicity index sensitive to subterranean species richness and ranking species weight of vulnerability (based on their frequencies); 2) ranking caves according to their endemicity index computed in a holistic concept for a geographic area. Our assessment is relevant in identifying the hotspots of vulnerable karst areas based on biospeleological data.

\section{METHODOLOGY}

\section{Dataset}

The dataset included in the present paper has been built during a comprehensive survey of the Romanian caves with endemic subterranean Arthropod species as synthesized in Nitzu et al. (2016), when 380 caves inhabited by a total of 278 endemic cave-dwelling (troglobitic and stygobitic) species and subspecies were inventoried) (Fig. 1). This database including all cave-dwellers distributed in the caves of the Romanian Carpathians and Dobrogea, was used to compute the synthetic EI. In this article we refer to unique species for the endemic species that occurred only in one cave. For endemic taxa we referred to the taxa distributed in caves confined to one (the 'unique' species/subspecies) or more caves from karst areas in the Carpathians or Dobrogea, but strictly confined to the studied geographic area of Romania (Fig. 2). We use the term endemism as given by the classical and generally accepted definition (Udvardy, 1969; Myers \& Giller, 1988; Myers \& De Grave, 2000). Each of the endemic stygobitic or troglobitic species and subspecies from the Romanian Carpathians or 


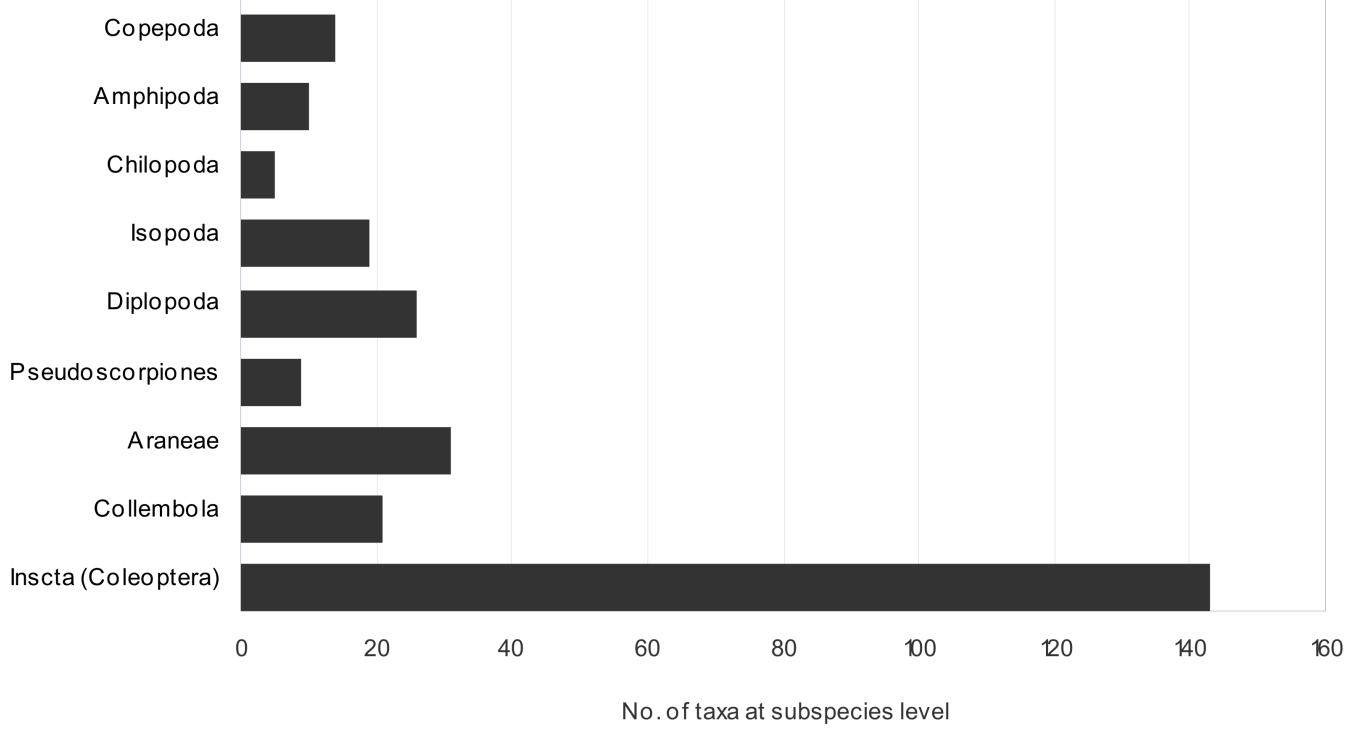

Fig. 1. Distribution of the endemic stygobitic and troglobitic taxa (at subspecies level) (Arthropoda) from the Romanian caves per taxonomic classes.

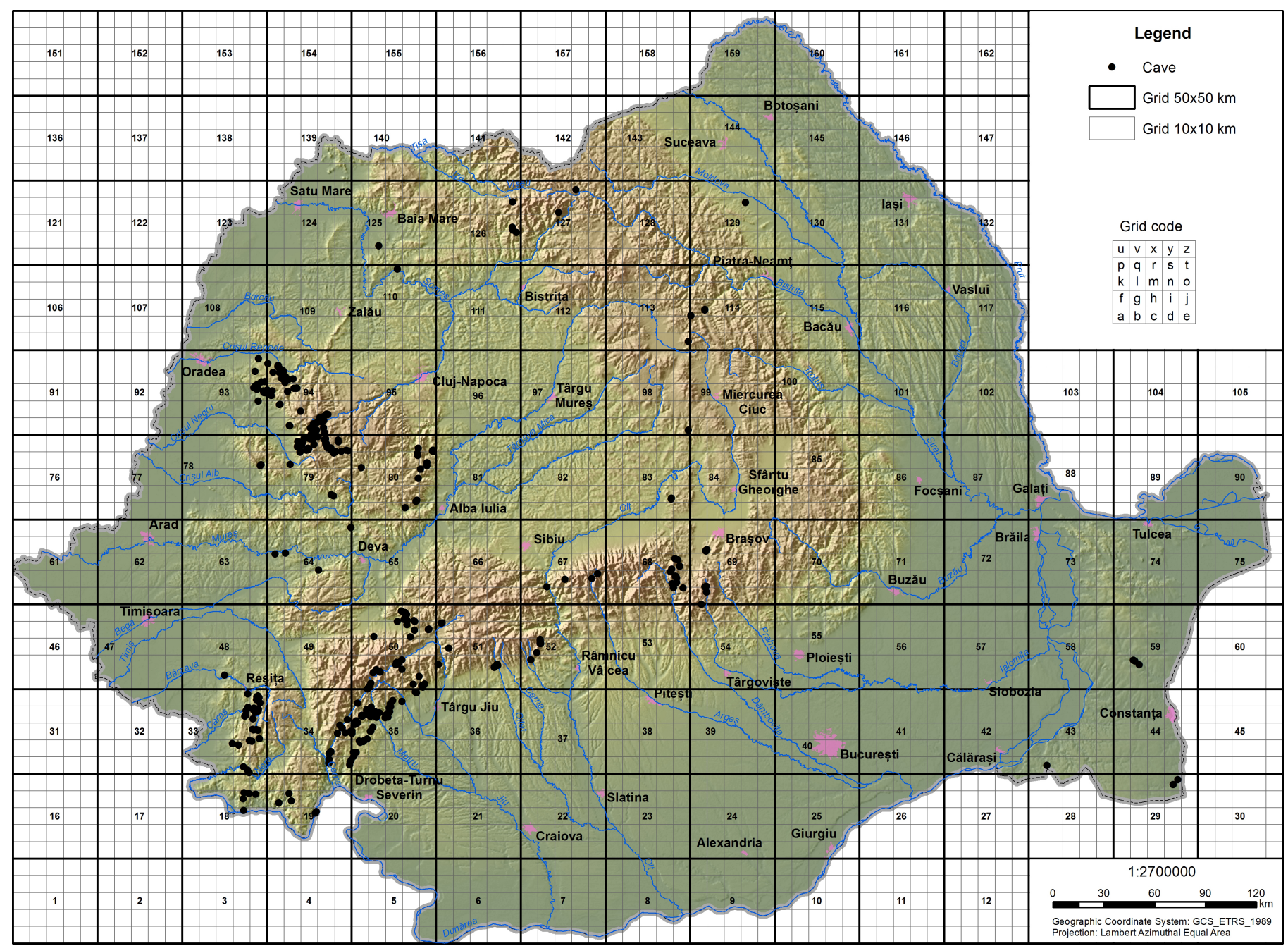

Fig. 2. The map of caves in the study area with endemic subterranean fauna.

Dobrogea taken into consideration in this article have distributions confined to karst areas of the Apuseni Mountains, Southern Carpathians, Eastern Carpatians or Dobrogea as in The Catalogue of Caves with Endemic Cavernicolous Arthropod Fauna of Romania (Nitzu et al., 2016).

The subspecies were taken into account when computing EI because we consider them major contributors to conservation plans: 1) in many circumstances subspecies are likely to prove useful in estimating the historical patterns of divergence among populations (O'Brien \& Mayr, 1991); 2) they are important in allopatric speciation, in terms of "gene-flow"; 3) even when molecular data are lacking to support the status of new species vs. subspecies, Phillimore \& Owens (2006) concluded that the overall level of congruence between taxonomic subspecies and molecular phylogenetic data is greater than 
previously thought. Because by definition, the cave habitat is fragmented and isolated (Sket, 1999) the subspecies have an increased probability of occurrence in it (considering that the cave-dwellers have narrow ecological requirements and low dispersion capacity). Therefore, troglobitic and stygobitic species are more inclined toward isolation and genome fragmentation and the presence of a large number of subterranean endemic subspecies argues for the age and the isolation of that fauna (Murienne et al., 2014; Giurginca et al., 2015). Regarding the importance of the subspecies in conservation plans, we totally agree with the conclusion of Phillimore \& Owens (2006) that 'subspecies may, in fact be of considerable conservation utility, as proxies for the sub-structure found within species...The conservation utility of subspecies is likely to be greatest in situations where the molecular data is absent' - a scenario that is likely to be frequently encountered in cave habitats. Besides, the endemic subspecies represent a major component of biodiversity and natural heritage (also included in international systematic databases like Fauna Europaea, Biolib, etc.), which oblige us to take them into consideration for conservation purposes.

\section{Endemicity index $(E I)$}

All the endemic arthropod species and subspecies were counted and ordered by their known frequency in the Romanian caves (Table 1). Further they were ranked on a relative scale of steps of species frequencies. A logarithmic distribution curve of species frequency was obtained (Fig. 3).

Table 1. The contribution of each supraspecific taxa (in alphabetic order) with endemic troglobitic and stygobitic species and subspecies to considered ranking taxa based on their frequency in caves. Step parameters reported for the total of 380 caves.

\begin{tabular}{|c|c|c|}
\hline $\begin{array}{l}\text { Frequency } \\
\text { rank (W) }\end{array}$ & Step parameters & $\begin{array}{c}\text { The total number of endemic species per step on the relative scale of frequencies } \\
\text { Amph = Amphipoda; Ara = Araneae; Chi = Chilopoda; Clmb = Collembola Cole = Coleoptera; } \\
\text { Cop = Copepoda } \text { Dpl = Diplopoda } \text { Iso = Isopoda; Pseu = Pseudoscorpiones. }\end{array}$ \\
\hline 1 & $\begin{array}{l}\text { Sp+ssp. recorded } \\
\text { in } 1 \text { cave }\end{array}$ & $4($ Amph $)+9($ Ara $)+1($ Chi $)+6($ Clmb $)+79($ Cole $+5(\mathrm{Cop})+9(\mathrm{Dpl})+11($ Iso $)+7($ Pseu $)=131$ \\
\hline 2 & $\begin{array}{c}\text { Sp+ssp. } \text { Recorded in } \\
2 \text { caves }\end{array}$ & $2(\mathrm{Amph})+6(\mathrm{Ara})+0(\mathrm{Chi})+6(\mathrm{Clmb})+33(\mathrm{Cole}(+4 \mathrm{Cop}+8(\mathrm{Dpl})+4 \mathrm{Iso}+1$ Pseu $=64$ \\
\hline 4 & $\begin{array}{l}\text { Sp+ssp. recorded } \\
\text { in 3-4 caves }\end{array}$ & $1(\mathrm{Amph})+6(\mathrm{Ara})+0(\mathrm{Chi})+6(\mathrm{Clmb})+18 \mathrm{Cole}+0(\mathrm{Cop})+3(\mathrm{Dpl})+1(\mathrm{Iso})+0(\mathrm{Pseu})=35$ \\
\hline 7 & $\begin{array}{l}\text { Sp+ssp. recorded } \\
\text { in } 5-7 \text { caves }\end{array}$ & $1 \mathrm{Amph}+2(\mathrm{Ara})+2(\mathrm{Chi})+1(\mathrm{Clmb})+8(\mathrm{Cole})+2(\mathrm{Cop})+2(\mathrm{Dpl})+1($ Iso $)+1(\mathrm{Pseu})=20$ \\
\hline 13 & $\begin{array}{l}\text { Sp+ssp. recorded } \\
\text { in } 8-13 \text { caves }\end{array}$ & $1(\mathrm{Amph})+3(\mathrm{Ara})+1(\mathrm{Chi})+1(\mathrm{Clmb})+3(\mathrm{Cole})+2(\mathrm{Cop})+0(\mathrm{Dpl})(+(2)$ Iso $+(0)$ Pseu $=13$ \\
\hline 22 & $\begin{array}{l}\text { Sp+ssp. recorded } \\
\text { in } 14-22 \text { caves }\end{array}$ & $1 \mathrm{Amph}+1(\mathrm{Ara})+0(\mathrm{Chi})+0(\mathrm{Clmb})+0($ Cole $)+1(\mathrm{Cop})+2(\mathrm{Dpl})+0($ Iso $)+0($ Pseu $)=5$ \\
\hline 37 & $\begin{array}{l}\text { Sp+ssp. recorded } \\
\text { in 23-37 caves }\end{array}$ & $0($ Amph $)+2($ Ara $)+1($ Chi $)+1(\mathrm{Clmb})+0($ Cole $)+0($ Cop $)+1(\mathrm{Dpl})+0($ Iso $)+0($ Pseu $)=5$ \\
\hline
\end{tabular}

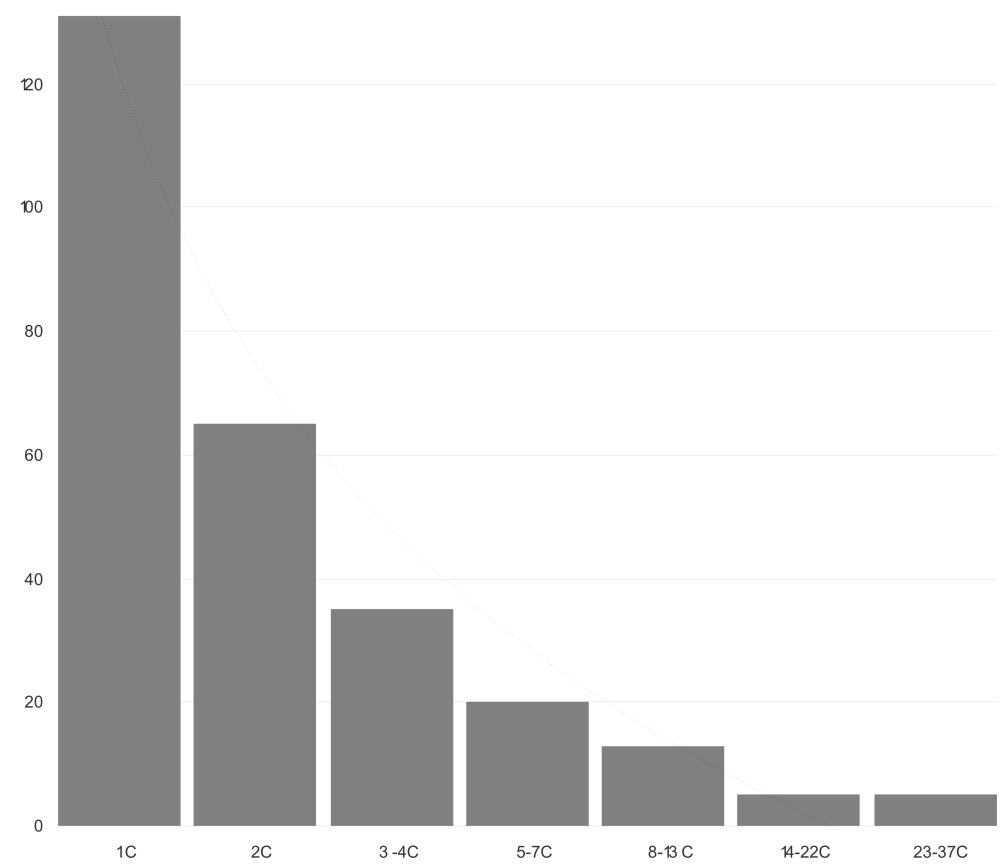

Fig. 3. The distribution of endemic taxa (at subspecies level) in caves (c) per classes of frequencies.

To better emphasise the differences between caves, according to their species richness and species rarity, we used a weighted relative scale, frequently used in landscape ecology (Turner et al., 2001). 'In weighting procedure, each objective is assigned to a fractional level of importance' (Gareth et al., 2000). In cases of relative (arbitrary) scales, the number of steps is assigned by authors for an optimal ranking (Saaty, 1993), but starting from the practical observed distribution of frequencies.

For a better reflection of the conservation importance of species related to their endemic status, each frequency step was weighted using the formula created for the logarithmic distribution, as follows:

$W($ step $)=\operatorname{trunc}\left(\operatorname{step}^{\left[1+\left(\log _{\text {stepmax }} G_{\max }-1\right) \frac{\text { step }-1}{\text { Stepmax }-1}\right]}\right)$

where $\mathrm{W}$ = computed weight assigned to a ranking step (here from one to seven) (weight function on step); Stepmax $=$ the number of the maximum steps of the relative scale (here = seven); Gmax = the number of caves in which the most frequent endemic species was recorded; Trunc $=$ adjusted to the nearest low integer number.

The most frequent endemic species received the maximum score of frequency $(\mathrm{W})$, and the rarest, the smallest one (the species occurring in one cave only will have $\mathrm{W}=1$ ).

The EI for each cave was calculated as follows:

$$
E I=\sum_{i=1}^{L} \frac{n i}{W i}
$$


where $\mathrm{L}=$ total number of steps from the relative scale of frequencies; $\mathrm{n}=$ total number of species belonging to each step, counted in cave; $\mathrm{W}=$ weight of each step. EI will take values from the lowest recorded values (cases with one endemic species belonging to the highest value of $\mathrm{W}$ ) to maximum.

An example of $E I$ calculation is provided below: for instance, for a cave with only one endemic species, a case recorded in 37 caves (the total number of caves in which that species occurred $=$ the known range of the species), according to Table 1 , the computed $\mathrm{W}$ for species occurrence in $23-37$ caves is $\mathrm{W}=37$ and the $E I=1 / 37=0.027(\approx 0.03)$

For Closani Cave (No. 12 in Supplemental Annex 1) we counted 1 species with $\mathrm{W}=1$ (unique species), $2 \mathrm{sp}$. with $\mathrm{W}=2$ (species recorded only in two caves), $2 \mathrm{sp}$. with $\mathrm{W}=4,5 \mathrm{sp}$. with $\mathrm{W}=7$ and $3 \mathrm{sp}$. with $\mathrm{W}=37$. Then, $E I=1 / 1+1 / 2+2 / 4+5 / 7+3 / 37=1+0.5+0.5+0.7$ $+0.081=2.781(\approx 2.8)$.

For Movile Cave we found 15 unique species (recorded only in one cave - Movile in this case) $(\mathrm{W}=1)$, and $2 \mathrm{sp}$. recorded in one more cave, so two caves in total $(\mathrm{W}=2)$. The $E I=15 / 1+2 / 2=16$. For our case of study, the Movile Cave has the maximum value of $E I$.

\section{Ranking caves according to their endemicity index for prioritization purposes}

Caves were ordered by their computed EI, and then ranked in classes of conservation concern based on a relative scale of endemicity, each class receiving a color code: dark red - caves with $E I>5$; red - caves with EI between 4 and 2; orange - caves with EI between 2 and 1 ; ocher - caves with $E I$ between 1 and 0.5 ; yellow - caves with $E I$ between 0.5 and 0.25 ; and light yellow - caves with $E I<0.25$.

\section{Mapping karst area vulnerability}

Further, the caves were mapped according to their coordinates (Fig. 2, Supplemental Annex 1) (Geographic Coordinate System GCS ETRS 1989, Projection Lambert Azimuthal Equal Area) using ArcGIS v. 10 (ESRI [Environmental Systems Research Institute], 2010). A feature grid with a cell size of 10 km2 was generated, using the Fishnet tool in ArcGIS. The caves were intersected with the generated fishnet polygons using spatial join tool, and a new feature class was created in the resulting polygon that records the number of caves within each square. The resulting grid has been converted in raster grid format and reclassified in five vulnerability classes. As our goal was to protect the endemic fauna "in situ", the entire cell area of protection has been taken into consideration, as resulted in the map of hotspots karst areas According to the caves belonging to each cell, and their related $E I$, each cell received a color. The map color bar varies from dark-red (the areas with the highest endemicity score and with the highest protection needs based on the related species) - to light yellow, according to the map color bar, corresponding to color codes of each class as explained above. The vulnerability class of each cell is given by the cave with highest $E I$ belonging to a particular cell.

\section{RESULTS AND DISCUSSIONS}

\section{Endemicity index}

As expected, a large number of species and subspecies were recorded only in one (131 sp. and ssp.) or few caves (Table 1), the distribution of their frequencies describing a logarithmic curve (Fig. 3). The high number of narrowly distributed species in caves of Romania align with previous findings that subterranean environments are characterized by a high percentage of endemic fauna confined to specific caves, as emphasized by studies conducted in the last decades all over the world (see Culver \& Sket, 2000; Christman et al., 2005; Eberhard et al., 2005; Stein et al., 2012; Iepure et al., 2016; Trajano et al., 2016).

The endemic taxa were ranked on seven steps of relative scale of frequencies, each step weighted from 1 (endemics reported in one cave) to 37 (endemics known from 23-37 caves) (Table 1). The maximum weight was given (accordingly to the $\mathrm{W}$ formula) by the most frequent species which occur, in our case, in 37 caves.

The Movile Cave presented the highest $E I=16$. The following 386 caves inhabited by endemic fauna, presented EI ranging from 4.05 to 0.03 (Supplemental Annex 1).

$E I$ proves to be very sensitive to number of taxa with $\mathrm{W}=1$ (15 endemic arthropod species were restricted to Movile Cave), but it is also influenced by each added number of endemic taxa with $\mathrm{W}$ higher than 1 that occurs in a cave. The 4-fold difference between the EI in Movile Cave and other caves is related to the peculiarity of Movile that is one of the most extreme cases of highly evolved chemosynthetically based ecosystem (Sarbu et al., 1996) supporting through its high productivity an outstandingly high percentage of cave-adapted endemic species (over 65\%) (Sarbu, 2000). The high diversity and species richness of the Movile Cave is also a consequence of its mesothermalism and of its historic biogeographic relation with the Euxinic glacial sub-refuge (Nitzu, 2001).

\section{Ranking caves according to their endemicity index for prioritization purposes}

According to their computed EI, the caves were ranked on a relative scale of six steps of conservation concern, each step receiving a color code (Supplemental Annex 1). Leaving aside the particular case of Movile Cave, 35 caves present a high EI (between 4.05 and 2); therefore these caves were assigned to the second class of conservation concern (red in Supplemental Annex 1). Most of these caves are inhabited by two or at least one unique taxa (recorded in only one cave), and also, by a considerable number of endemic taxa, recorded up to present just in few caves. Davies et al. (2004) stressed that both species rarity and specialized adaptations may increase the risk of species extinction independently, even synergistically. Cave-dwelling fauna, with its narrow distribution ranges and adaptive specialized traits developed to cope with the subterranean environment, is no exception. Consequently, we consider that the 
aforementioned caves should be of high conservation concern, to protect the endemic subterranean fauna they shelter.

The same conservation concern concept should be applied to caves listed in the third class of conservation concern (72 caves with EI ranging from 1.94 to 1 (orange in Supplemental Annex 1). Despite their lower diversity in terms of endemic taxa, in comparison with caves clustered in second class of conservation concern, these caves are also populated by unique taxa or by or taxa with extremely narrow distribution (most of them with one endemic taxa recorded in one or two caves).

The fourth class of conservation concern includes 58 caves with EI between 0.94 and 0.5 (ocher in Supplemental Annex 1). These caves are inhabited by endemic stygobitic and troglobitic taxa with distribution ranges confined to two or four caves. Finally, the next two classes of conservation concern include caves with $E I<0.5$ (yellow and light yellow in Supplemental Annex 1). The caves clustered in the fifth class, with $E I$ ranging from 0.45 to 0.25 , is inhabited by endemic fauna encountered in few caves (3-4 caves) to up to 37 caves, from a small geographic area that should be protected by local conservation plans.

In a broad sense, rare species play an important role in the ecosystem composition and functioning as follows: 1) they contribute to the maintenance of ecosystem diversity; 2) they might be indicators of species diversity patterns (Lyons et al., 2005). In the context of subterranean environments, the aquatic narrowly distributed species maintain a high water quality through water purification, bioremediation, water infiltration and transport (Boulton et al., 2008; Griebler et al., 2010), while their persistence underground is an indicator of surface-groundwater system health (Meleg et al., 2014). In our study most of the endemic stygobitic and troglobitic species are rare and narrowly distributed; therefore their presence in the studied caves is an essential driver in maintaining the ecosystem's dynamic equilibrium (Culver et al., 2006; Culver \& Pipan, 2014). As such, we consider EI a good proxy for assessing protection priorities for caves and karst areas as follows: caves where high EI were recorded should be prioritized at national level in terms of conservation concern, while those with low EI should be included in regional conservation agendas.

\section{Mapping karst area vulnerability}

Caves and karst areas are considered to be highly sensitive to various environmental and disturbance factors associated with epigean invasive species (Wynne et al., 2014), deforestation (Trajano, 2000) and global climate change (Mammola et al., 2017). Given the peculiarities and vulnerability of cave ecosystems and karst landscapes, their preservation and protection should be of particular concern. Although large karst areas in Romania (75.65 \%) are included in already-designated protected areas, there are no taken actions to prove that the environmental policy provides a sustainable framework for subterranean fauna and karst conservation. The caves were mapped by assigning them color codes related to their
EI to highlight the karst areas of highest conservation concern (Fig. 4). Based on our assessment, Movile is the cave with the highest concern for protection. This cave is protected by the Romanian law as subterranean habitat of high interest based on its geological importance (Law no. 49/2011) and it is also protected as habitat $\mathrm{H} 8310$ (the code for Caves not open to public) within the Natura 2000 Network under the European Habitat Directive 42/93. Unfortunately, 22 of the other 35 caves of high conservation concern (grouped in the second class) are still unprotected because of missing legislative frame for protection of endemic stygobitic and troglobitic fauna in Romania. The lack of proper conservation plans dedicated to invertebrates that are frequently island or cave inhabitants (Martin et al., 2010), has been discussed by Cardoso et al. (2011). They emphasized the impediments due to which invertebrates (even though most susceptible to habitat loss) are often neglected in biodiversity conservation policies. This gap in the conservation plans of endemic invertebrate subterranean fauna in Romania was up to present justified by the lack of any synthetic assessment of hotspot areas from a biospeleological point of view. We hope that our contribution offers a feasible solution to the above mentioned shortcomings, by proposing a general scientific method for assessing the vulnerability of karst areas, and also to map the hotspots of vulnerable karst areas in Romania based on the presence of endemic cavernicolous species of conservation concern.

\section{Comparison of $E I$ with other published indices proposed for conservation purposes}

For the BCC index, Fattorini has used a linear scale with eight steps (equal weighting steps), based on the 0/1 principle to assess the contribution to weighting of three parameters: abundance (high/low), biotope (wide/narrow) and range (wide/narrow). For EI we firstly counted the number of species occurring from one to the maximum number of caves, and then by taking into account the observed logarithmic scale of species frequency distribution, we differentially weighted each step of the relative scale in order to increase the statistical power of unique species and species occurring only in two caves, in comparison to the most frequent species (in our case species recorded in 22 to 37 caves) (Table 1 ).

In the present study, we provide a formula adapted to a logarithmic distribution of species frequencies (a type of statistical distribution common in caves) for weighting each step of the relative scale, reducing the risk of biased values of computed endemicity index. Generally speaking (independent of what cavedwelling or epigean species contributed to the observed pattern), applying an arbitrary weight to each step of a relative scale, while ignoring the real distribution of frequencies values, would bias the final results. For instance, applying a linear (equal) weighting to each step for an observed logarithmic distribution of the frequencies (or Gaussian distribution - as observed for the most of epigean species), will arbitrary reduce or increase the importance of that step (or class). In 


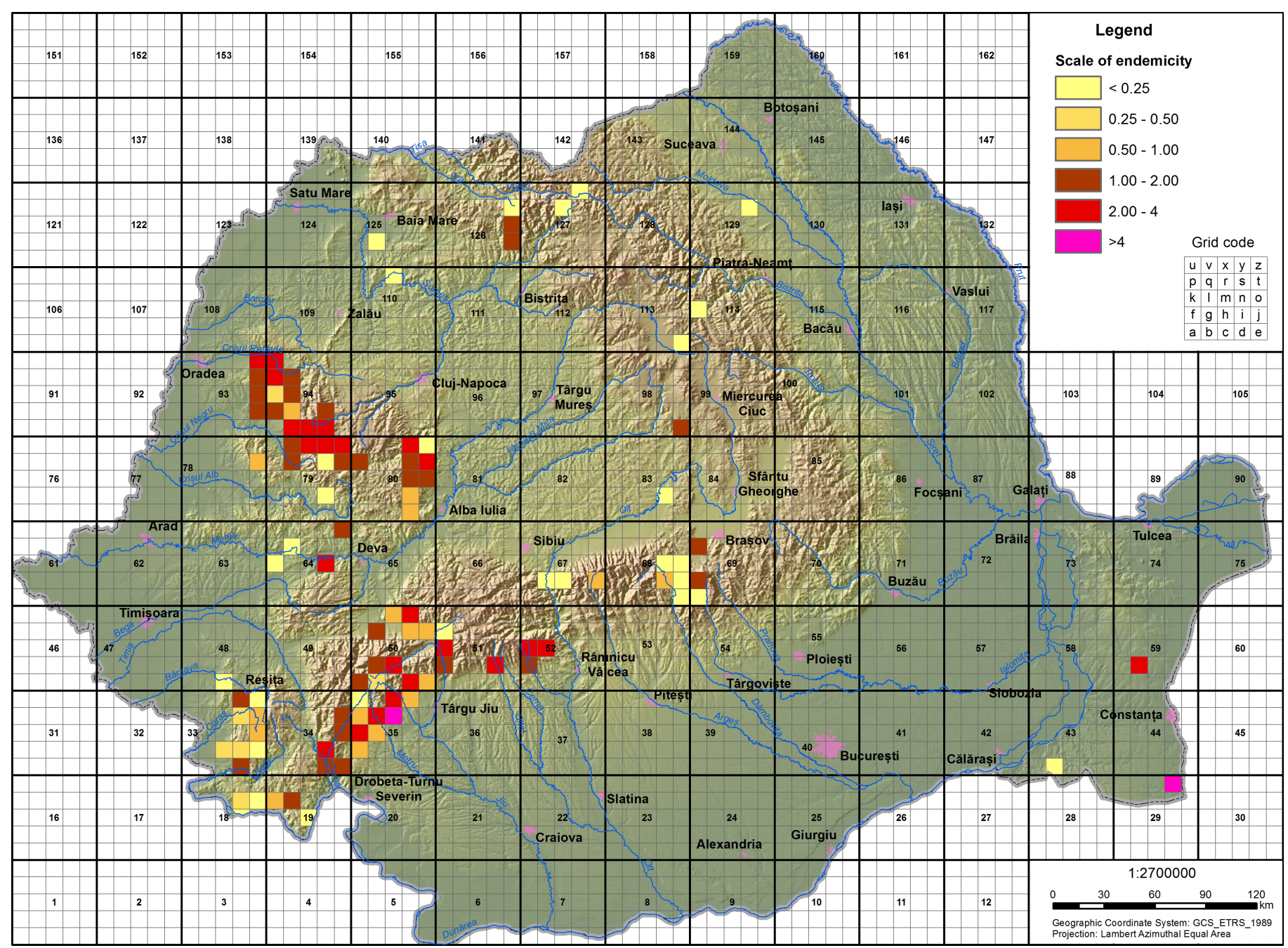

Fig. 4. The map of hotspot karst areas based on endemicity scale.

other words, a weight incorrectly assumed to a specific step of the relative ranking scale, would lead to errors in the final interpretation.

In comparison to the Biodiversity Conservation Weight index (BCW) proposed by Fattorini \& Dapporto (2014) to correct the biased BCC index, in which the authors have used the ratio between local and total weights (a), we used the ratio between the number of species (n) and the weight of each class of frequency.

An interesting methodology for reserve selection for conserving groundwater biodiversity, including three selection methods (species richness hotspots, endemism hotspots and complemetareity) has been described by Michel et al. (2009). We believe that assessing the role of species richness and endemicity indices individually and by comparison in designing protected areas and networks is most appropriate for large scale geographic areas, when the regional endemicity contributes highly to observed patterns. For smaller geographic areas, especially when the protection of caves (small and isolated habitats) is aimed, we consider that a synthetic index (EI) including richness of endemic species weighted on their frequencies is more suitable, having in mind that in caves, the most vulnerable species are the endemic cave-dwellers with very narrow ranges and they contribute significantly to the subterranean biodiversity. Michel et al. (2009) started from the premise that choose an arbitrary threshold level of $10 \%$ of all geographic cells (4675 grid cells -0.2 $x$ 0.20) would best represent the diversity of the stygobitic fauna in six countries for reserve selection purpose. In our study, based both on stygobitic and troglobitic endemic fauna, we distributed the species on an arbitrary (relative) scale of seven weighted steps of frequencies. Then we computed the EI for each cave. At the end, depending on their EI values, the caves were ranked for protection priorities purpose.

At a larger geographic scale, Michel et al. (2009), have taken into consideration the species penalty factor (SPF) computed with MARXAN software for reserve selection to protect groundwater biodiversity. As the authors mentioned 'SPF is a weighting factor which determines the relative importance for adequately representing a particular species'. This penalty is given to the species that have not met their representation target. Broadly speaking, SPF determines to what priority each individual target or feature can accomplish its goal. As the quoted authors have observed, 'the complementary areas obtained without species penalties were almost efficient as endemism hotspots because (i) the endemism hotspots are complementary by nature and (ii) endemic species themselves strongly influence the cell selection process as they constitute a high proportion of the total richness of groundwater fauna'. Comparatively, the $E I$ is a weighting index which determines the relative importance for adequately representing the 
contribution of each endemic species (function of its frequency in the entire studied area), in species association of a particular case (cave in our case).

For cave habitats, in the Azores Islands, Borges et al. (2004) proposed a multiple criteria index entitled 'Importance Value for Conservation' (IV-C), incorporating arthropod species diversity together with: geology index, difficulty of exploration index, threats index, integrity index, accessibility index. This methodology is hard to follow and ambiguous establishing the reliable factors for protection. As the authors have asserted 'when different values of criteria are combined in a single index, it is difficult to know what the single value obtained from it represents' (Borges et al., 2004). In a further publication (Borges et al., 2012) the authors have tried to correct this inconvenient, but the proposed methodology remains hard to follow. By contrast, $E I$ based on the frequency of endemic cave-dwelling species, overcomes difficulties that may arise when interpreting multiple criteria indices or biased results that may appear due to a higher weighting than normal of a given feature, as mentioned for IV-C index (Borges et al., 2004).

\section{CONCLUSIONS}

For biologists the protection of rare and endangered species is by itself an important aim in biodiversity conservation and furthermore their presence in specific areas makes them suitable candidates in assessing and designating protected areas. In former protection studies, the endemic species were used in addition to other rare species in conservation priorities of islands (Fattorini \& Dapporto, 2014), or incorporated in a complex index (Borges et al., 2004, 2012) for conservation priorities in lava tubes. In this article, we proposed an index of endemicity conceived to protect "in situ" the endemic stygobitic and troglobitic species, ranking the caves based on their endemicity index (EI). The EI is sensitive both to species richness and their vulnerability, able to solve the problems raised by the above mentioned indices. The authors of the formerly quoted studies also ranked the species in relative scales. In our article we provide a formula based on logarithmic distribution of species frequencies for weighting each step of the relative scale to reduce the risk of biased values of EI. Based on the cave's EI, we obtained the map of karst area vulnerability and the related hotspots of 'conservation concern'.

The proposed EI was generated as a solution for prioritization of small and isolated habitats (caves) at medium scale, different by the suitable solutions available for reserve selection in continuous groundwater habits, at large scale areas (Michel et al., 2009). At medium scale geographic areas (taking into consideration that is compulsory to include the entire ranges of the considered endemic cave-dwelling species of a studied geographic area), the proposed index can be used to protect the caves with high endemic fauna, without establishing a threshold, but on a scale of their vulnerability, thus avoiding the risk of under-representing or excluding the endemic species of interest.

Our results have proven reliable and robust, therefore, we consider that the focus should be on the primary factors, such as species richness and endemicity, when protection and preservation considerations with regard to cavernicolous (troglobitic and stygobitic) species and their habitat are developed on small (i.e., confined to a small geographic area like caves from a mountain massif) to medium scale geographic area (i.e., the Carpathian, Balkan, Mediterranean areas).

In future studies, we intend to corroborate biospeleological conservation concern data with information regarding the complexity of other elements of conservation concern in subterranean environments (i.e., functional diversity, source-sink dynamics, geology, hydrology, impacts and threats), to asses a comprehensive prioritization of caves and karst area in the context of their preservation, protection and sustainable management. Then, comparing all those different criteria of vulnerability, we will be able to establish which cave is most vulnerable to which factor.

\section{ACKNOWLEDGMENTS}

The present study has been undertaken within the framework of Program I, Project 1 of the "E. Racoviță" Institute of Speleology of the Romanian Academy. The authors express their gratitude to Drs. David Culver, Stefano Mammola, Tanja Pipan and to an unknown reviewer for their valuable suggestions, critical observations and corrections which led to an improvement of the general structure of the manuscript.

\section{REFERENCES}

Borges P.A.V., Pereira F. \& Constância J.P., 2004 Indicators of conservation value of Azorean caves based on its Arthropod fauna. Association for Mexican Cave Studies (AMCS) Bulletin, 19/ Socieded Mexicana de Exploraciones Subterráneas (SMES) Boletin, 7: 109-113.

Borges P.A.V., Cardoso P., Amorim I.R., Pereira F., Constancia J.P., Nunes J.C., Barcelos P., Costa P., Gabriel R. \& Dapkevicius M.D.L., 2012 - Volcanic caves: priorities for conserving the Azorean endemic troglobiont species. International Journal of Speleology, 41 (1): 101-112.

https://doi.org/10.5038/1827-806X.41.1.11

Boulton A.J., Fenwick G.D., Hancock P.J. \& Harvey M.S., 2008 - Biodiversity, functional roles and ecosystem services of groundwater invertebrates. Invertebrate Systematics, 22: 103-116. https://doi.org/10.1071/IS07024

Cardoso P., Borges P.A.V., Triantis K.A., Ferrández M.A. \& Martin H.L., 2010 - Adapting the IUCN Red List criteria for invertebrates. Biological Conservation, 144: 24322440. https://doi.org/10.1016/j.biocon.2011.06.020

Cardoso P., Erwin T.L., Borges P.A.V. \& New T.R., 2011 - The seven impediments in invertebrate conservation and how to overcome them. Biological Conservation, 144: 2647-2655.

https://doi.org/10.1016/j.biocon.2011.07.024 
Castellarini F., Malard F., Dole-Olivier M.-J. \& Gibert J., 2007 - Modelling the distribution of stygobionts in the Jura Mountains (eastern France). Implications for the protection of ground waters. Diversity and Distributions, 13: 213-224.

https://doi.org/10.1111/j.1472-4642.2006.00317.x

Chape S., Harrison J., Spalding M. \& Lysenko I., 2005 - Measuring the extent and effectiveness of protected areas as an indicator for meeting global biodiversity targets. Philosophical Transactions of the Royal Society of London, Series B, 360: 443-455.

https://doi.org/10.1098/rstb.2004.1592

Christman M.C., Culver D.C., Madden M.K. \& White D., 2005 - Patterns of endemism of the eastern North American cave fauna. Journal of Biogeography, 32: 1442-1452.

https://doi.org/10.1111/j.1365-2699.2005.01263.x

Cook J.A. \& MacDonald S.O., 2001 - Should endemism be a focus of conservation efforts along the North Pacific Coast of North America? Biological Conservation, 97: 207-213.

https://doi.org/10.1016/S0006-3207(00)00113-0

Culver D.C. \& Sket B., 2000 - Hotspots of subterranean biodiversity in caves and wells. Journal of Cave and Karst Studies, 62: 11-17.

Culver D.C., Deharveng L., Bedos A., Lewis J.J., Maden M., Reddell J.R., Sket B., Trontelj P. \& White D., 2006 - The mid-latitude biodiversity ridge in terrestrial cave fauna. Ecography, 29: 120-128. https://doi.org/10.1111/j.2005.0906-7590.04435.x

Culver D.C. \& Pipan T., 2014 - Shallow subterranean habitats. Ecology, evolution, and conservation. Oxford University Press, 258 p. https://doi.org/10.1093/acprofso/9780199646173. $\underline{001.0001}$

Davies K.F., Margules C.R. \& Lawrence J.F., 2004 - A synergistic effect puts rare, specialized species at greater risk of extinction. Ecology, 85: 265-271. https://doi.org/10.1890/03-0110

Decu V. \& Racoviță G., 1994 - Roumanie. In: Juberthie C. \& Decu V. (Eds.), Encyclopaedia Biospeologica. Editura Fabbro, Saint Girons, 1: 779-802.

Eberhard S.M., Halse S.A. \& Humphreys W.F., 2005 Stygofauna in the Pilbara region, north-west Western Australia: A review. Journal of the Royal Society of Western Australia, 88: 167-176.

Ervin J., 2003 - Protected area assessments in perspective. Bio Science, 53: 819-822 https://doi.org/10.1641/0006-3568(2003)053 [0819:PAAIP]2.0.CO;2

ESRI 2011 - ArcGIS Desktop: Release 10. Redlands, CA: Environmental Systems Research Institute.

Fattorini S., 2006 - A new method to identify important conservation areas applied to the butterflies of the Aegean Islands (Greece). Animal Conservation, 9: 75-83. https://doi.org/10.1111/j.1469-1795.2005.00009.x

Fattorini S., 2010 - Use of insect rarity for biotope prioritisation: the tenebrionid beetles of the Central Apennines (Italy). Journal of Insect Conservation, 14: 367-378.

https://doi.org/10.1007/s10841-010-9266-6

Fattorini S., Cardoso P., Rigal F. \& Borges P.A., 2012 Use of Arthropod rarity for area prioritisation: Insights from Azorean Islands. PLoS ONE, 7 (3): 1-9. https://doi.org/10.1371/journal.pone.0033995

Fattorini S., Di Giulio A. \& Dapporto L., 2013 - Measuring insect rarity: practical issues, pragmatic approaches. Journal of Insect Biodiversity, 1 (10): 1-21.

https://doi.org/10.12976/jib/2013.1.10
Fattorini S. \& Dapporto L., 2014 - Assessing small island prioritization using species rarity: the tenebrionid beetles of Italy. Journal of Integrated Coastal Zone Management, 14 (2): 185-197.

Gareth E.J., Davies B. \& Hussain H., 2000 - Ecological Economics: An introduction. Blackwell Science, 272 p.

Gibert J., Culver D.C., Dole-Olivier M.-J., Malard F., Christman M.C. \& Deharveng L., 2009 - Assessing and conserving groundwater biodiversity: synthesis and perspectives. Freshwater Biology, 54: 930-941.

https://doi.org/10.1111/j.1365-2427.2009.02201.x

Giurginca A., Munteanu C.-M., Vlaicu M., \& Tabacaru I., 2015 - Cavernicolous Oniscidea of Romania. Ed. Semne, Bucharest, 169 p.

Griebler C., Stein H., Kellermann C., Berkhoff S., Brielmann H., Schmidt S., Selesi D., Steube C., Fuchs A. \& Hahn H.J., 2010 - Ecological assessment of groundwater ecosystems. Vision or illusion? Ecological Engineering, 36: 1174-1190.

https://doi.org/10.1016/j.ecoleng.2010.01.010

Gounand H.I., Ward C. \& Altermatt F., 2017 - Bridging ecology and conservation: from ecological networks to ecosystem function. Journal of Applied Ecology, 54: 371-379. https://doi.org/10.1111/1365-2664.12769

Iepure S., Feurdean A., Bădăluță C., Nagavciuc V. \& Perşoiu A., 2016 - Pattern of richness and distribution of groundwater Copepoda (Cyclopoida: Harpacticoida) and Ostracoda in Romania: an evolutionary perspective. Biological Journal of the Linnean Society, 119: 593-608. https://doi.org/10.1111/bij.12686

Jaffé R., Prous X., Zampaulo R., Giannini T.C., ImperatrizFonseca V.L., Maurity C., Oliveira G., Brandi I.V. \& Siqueira J.O., 2016 - Reconciling mining with the conservation of cave biodiversity: A quantitative baseline to help establish conservation priorities. PLoS ONE 11 (12): e0168348.

https://doi.org/10.1371/journal.pone.0168348

Juberthie C., 2000 - Conservation of subterranean habitats and species. In Wilkens H.D., Culver D., \& Humphreys W.F. (Eds.), Subterranean ecosystems. Amsterdam: Elsevier, p. 691-700.

Lyons K.G., Brigham C.A., Traut B.H. \& Schwartz M.W, 2005 - Rare species and ecosystem functioning. Conservation Biology, 19: 1019-1024. https://doi.org/10.1111/j.1523-1739.2005.00106.x

Mammola S., Goodacre S.L. \& Isaia M., 2017- Climate change may drive cave spiders to extinction. Ecography, 40: 1-10. https://doi.org/10.1111/ecog.02902

Martín J.L., Cardoso P., Arechavaleta M., Borges P.A.V., Faria B.F., Abreu C., Aguiar A.F., Carvalho J.A., Costa A.C., Cunha R.T., Fernandes F.M., Gabriel R., Jardim R., Lobo C., Martins A.M.F., Oliveira P., Rodrigues P., Silva L., Teixeira D., Amorim I.R., Homem N., Martins B., Martins M. \& Mendonça, E., 2010 - Using taxonomically unbiased criteria to prioritize resource allocation for oceanic island species conservation. Biodiversity and Conservation, 19: 1659-1682. https://doi.org/10.1007/s10531-010-9795-Z

Meleg I.N., Moldovan O.T., Iepure S., Fiers F., \& Brad T., 2011-Diversity patterns of fauna in dripping water of caves from Transylvania. Annales de Limnologie International Journal of Limnology, 47: 185-197. https://doi.org/10.1051/limn/2011014

Meleg I.N., Năpăruş M., Fiers, F., Meleg H.I., Vlaicu M. \& Moldovan O.T., 2014 - The relationships between land cover, climate and cave copepod spatial distribution and suitability along the Carpathians. Environmental Conservation, 41: 206-216. https://doi.org/10.1017/S0376892913000465 
Meyers N., Mittermeier R.A., Mittermeier C.G., da Fonseca G.A.B. \& Kent J., 2000 - Biodiversity hotspots for conservation priorities. Nature, 403: 853-858. https://doi.org/10.1038/35002501

Michel G., Malard F., Deharveng L., Di Lorenzo T., Sket B. \& De Broyer C., 2009 - Reserve selection for conserving groundwater biodiversity. Freshwater Biology, 54: 861876. https://doi.org/10.1111/j.1365-2427.2009.02192.x

Murienne J., Daniels S.R., Buckley T.R., Mayer G. \& Giribet, G., 2014 - A living fossil tale of Pangaean biogeography. Proceedings of the Royal Society B, 281: 1-9. https://doi.org/10.1098/rspb.2013.2648

Myers A.A. \& Giller P.S., 1988, - Analitical Biogeography. An integrated approach to the study of animal and plant distributions. Chapma and Hall, London, New York, 578 p.

Myers A.A. \& De Grave S., 2000 - Endemism: origins and implications. Vie Milieu, 50: 195-204.

Nitzu E., 2001 - Edaphic and subterranean Coleoptera from the Dobrogean karstic areas. A zoogeographic approach. Mitteilungen aus den Hamburgischen Zoologischen Museum und Institut, 98: 131-169.

Nitzu E., Giurginca A., Nae A., Popa I., Baba S., Meleg I.N. \& Vlaicu M., 2016 - The catalogue of caves with endemic cavernicolous arthropod fauna of Romania. Travaux de 1'Institut de Spéologie "Emile Racovitza", 55: 3-62.

O'Brien S.J. \& Mayr E., 1991 - Bureaucratic mischief: recognizing endangered species and subspecies. Science, 251: 1187-1188. https://doi.org/10.1126/science.251.4998.1187

Pipan T. \& Culver D.C., 2012 - Convergence and divergence in the subterranean realm: A reassessment. Biological Journal of the Linnean Society, 107: 1-14. https://doi.org/10.1111/j.1095-8312.2012.01964.x

Phillimore A.B. \& Owens P.F., 2006 - Are subspecies useful in evolutionary and conservation biology? Proceedings of the Royal Society B, 273: 1049-1053. https://doi.org/10.1098/rspb.2005.3425

Saaty T.L., 1993 - What is relative measurement? The ratio scale phantom. Mathematical and Computer Modelling, 17 (4-5): 1-12.

https://doi.org/10.1016/0895-7177(93)90170-4
Sarbu S.M., Kane T.C., \& Kinkle B.K., 1996 - A chemoautotrophically based cave ecosystem. Science, 272: 1953-1955.

https://doi.org/10.1126/science.272.5270.1953

Sarbu S.M., 2000 - Movile Cave: A chemoautotrophically based groundwater ecosystem. In: Wilkens H.D., Culver D. \& Humphreys W.F. (Eds.), Subterranean ecosystems. Amsterdam, Elsevier, p. 319-343.

Stein H., Griebler C., Berkhoff S., Matzke D., Fuchs A. \& Hahn H.J. 2012 - Stygoregions - a promising approach to a bioregional classification of groundwater systems. Scientific Reports, 2: 1-9. https://doi.org/10.1038/srep00673

Sket B., 1999 - High biodiversity in hypogean waters and its endangerment - the situation in Slovenia, the dinaric karst, and Europe. Crustaceana, 72: 767-780. https://doi.org/10.1163/156854099503951

Stoch F. \& Galassi D.M.P., 2010 - Stygobiotic crustacean species richness: a question of numbers, a matter of scale. Hydrobiologia, 653: 217-234. https://doi.org/10.1007/s10750-010-0356-y

Trajano E., 2000 - Cave faunas in the Atlantic tropical rain forest: Composition, ecology and conservation. Biotropica, 32: 882-893.

https://doi.org/10.1111/j.1744-7429.2000.tb00626.x

Trajano E., Gallao J.E., \& Bichuette, M.E., 2016 - Spots of high diversity of troglobites in Brazil: the challenge of measuring subterranean diversity. Biodiversity and Conservation, 25 (10): 1805-1828. https://doi.org/10.1007/s10531-016-1151-5

Turner M.G., Gardner R.H. \& O'Neill R.V., 2001 Landscape ecology in theory and practice. New York. Springer Verlag, $401 \mathrm{p}$.

Udvardy M.D.F., 1969 - Dynamic zoogeography. With special reference to land animals. Van Nostrand Reinhold Company, New York, 445 p.

Wynne J.J. Bernard E.C., Francis G.H., Sommer S., Soto-Adames F.N., Taiti S., Mockford E.L., Horrocks M., Pakarti L. \& Pakarti-Hotus V., 2014 - Disturbance relicts in a rapidly changing world: the Rapa Nui (Easter Island) factor. BioScience, 64 (8): 711-718. https://doi.org/10.1093/biosci/biu090 